\title{
Distribution Pattern and Characteristics of Grey Starling Sturnus cineraceus Summer Roosts in the Eastern Kanto Area
}

\author{
Makiko Takenaka and Sen Takenaka \\ Hokkaido Tokai University, Minaminosawa 5-jo, 1-chome Minami-ku, Sapporo 005
}

The Grey Starling Sturnus cineraceus roosts communally in Japan. In the eastern Kanto, Grey Starlings occupy large-numbered summer roosts between June and October. Although the existence of summer roosts had been reported, the distribution pattern of summer roosts over a large area was not known. We located 14 summer roosts in the eastern Kanto and analyzed their distribution pattern using the $I_{\delta}$ index. Our analysis revealed that they were uniformly distributed. All of the summer roosts in our study area were occupied from late June or early July to mid-October. The Grey Starling did not seem to favor a particular vegetation type to roost during summer, which was contrasting to their preference for bamboos in winter. Since several factors are involved in the occupation and abandonment of summer roosts, it is difficult to determine the very factor directly influencing them. The uniform distribution of summer roosts might be related to the life history of the Grey Starling, and might be convenient for the starlings accompanying inexperienced young to feeding grounds.

Key Words: Distribution pattern, Grey Starling, Summer Roost

In some parts of the Kanto area, summer roosts with large numbers of Grey starlings Sturnus cineraceus have been found (KURODA 1955, 1956, 1960, 1973, NARUSUe et al. 1987, TAKenAKa et al. 1987). The Kanto area is a vast plain, and it is probable that many such summer roosts exist. However, the distribution pattern of summer roosts in a large area has not been elucidated. We analyzed the spatial relationship of summer roosts located in the eastern Kanto area, which is a relatively less urbanized part of the Kanto plain. In particular, we tested whether or not the summer roosts were evenly spaced.

\section{STUDY AREA AND METHODS}

Our study area was in the eastern Kanto area, including southern Ibaraki, eastern Saitama and the northern part of Chiba. The study area was approximately 3,000 $\mathrm{km}^{2}$ and was the flattest part of the plain, consisting mainly of cultivated areas with rice paddies and isolated wooded windbreaks.

Our study was conducted between June and October in 1984, 1985 and 1986. In our preliminary observation, we found that Grey Starlings started to occupy summer roosts in June or July and evacuated them in October in Tsukuba. We determined the location of summer roosts by using cars to follow flightlines of Grey Starlings heading towards roost sites in late afternoon. We began our search about $1 \mathrm{~h}$ before sunset. When we found flocks flying in a different direction from the roost sites that we had found, we followed them to find new roost sites. We did not include small roosts with less than 500 starlings, because these roosts were sporadic and lasted 
only several days after breeding. At each roost site, we counted the number of assembling Grey Starlings, recorded the vegetation type of the roost area and asked people living near the roost about the season of roost-site occupation, the age of the roost and other information.

We calculated the $I_{\delta}$ index (Morishita's index) for the distribution of summer roosts found during the study period. The equation,

$$
I_{\delta}=n \frac{\sum_{i=1}^{n} x_{i}\left(x_{i}-1\right)}{N(N-1)}
$$

where $n$ is the number of quadrats in the study area, $N$ is the total number of roosts and $x$ is the number of roosts fund in the $i$ th quadrat, was used (MoRIsHita 1959). When the value of $I_{\delta}$ is smaller than 1, the distribution pattern is said to be uniform. We included all the summer roosts with known location in calculating the $I_{\hat{\sigma}}$

\section{RESULTS}

Table 1 shows the number of Grey Starlings assembling at the summer roosts. The number of starlings at the summer roosts were between several thousand and 30,000.

In 1985, local people used firecrackers and other threatening devices to force starlings to abandon Roost No. 6 in June and July during the Science Expo '85. Starlings were observed to fly in different directions for nearly a month and finally roosted in Doho (No. 6' in Figure 1, Tables 1, 2 and 3), a park located only $2 \mathrm{~km}$ south

Table 1. The number of assembling Grey Starlings at summer roosts to the nearest hundreds. The dates when countings were made are indicated in parentheses. The numbers of the left column correspond to those in Fig. 1. "+" means that a roost existed but the number of assembling starlings was not known. " $x$ " means that roost was abandoned. "-" stands for no survey done.

\begin{tabular}{|c|c|c|c|}
\hline \multirow{2}{*}{ Roost } & \multicolumn{3}{|c|}{ Year } \\
\hline & 1984 & 1985 & 1986 \\
\hline \multirow[t]{2}{*}{1.} & - & 29,000 (Jul 5) & - \\
\hline & & 29,900 (Oct 3 ) & - \\
\hline 2. & - & 23,300 (Oct 2 ) & - \\
\hline 3. & - & + & + \\
\hline 4. & - & 26,000 (Jul 28) & - \\
\hline 5. & - & 10,000 (Jul 15) & - \\
\hline \multirow[t]{3}{*}{6.} & 25,000 (Aug 25) & 34,500 (Jul 13) & $\times$ \\
\hline & $30,000(\operatorname{Sep} 6)$ & 25,000 (Jul 19) & \\
\hline & $15,000$ (Oct 11$)$ & & \\
\hline $6^{\prime}$ & not used & $>7,000$ (Aug 14) & $10,300(\mathrm{Jul} \mathrm{11})$ \\
\hline 7. & $10,000($ Oct 4$)$ & $10,000($ Jun 26$)$ & 8,000 (Jul 15) \\
\hline 8. & - & 23,000 (Oct 6) & - \\
\hline 9. & - & $13,400(J u l ~ 12)$ & 6,500 (Jun 20 ) \\
\hline 10. & - & $8,800(\operatorname{Sep} 12)$ & - \\
\hline 11. & - & - & $7,100(\operatorname{sep} 22)$ \\
\hline 12. & - & - & $+*$ \\
\hline 13. & - & - & $+*$ \\
\hline 14. & $+*$ & $+*$ & $+*$ \\
\hline
\end{tabular}

* Personal communications. 
Table 2. Vegetation of summer roosts in eastern Kanto area. The number on the left column correspond to those in Fig. 1.

\begin{tabular}{ll}
\hline \multicolumn{1}{c}{ Roost } & \multicolumn{1}{c}{ Vegetation } \\
\hline 1. Mito & $\begin{array}{l}\text { Japanese Red Cedar Cryptomeria japonia, Moso Bamboo } \\
\text { Phyllotachys heterocycla } \\
\text { Japanese Red Cedar }\end{array}$ \\
2. Ogawa & Reed Phragmites communis \\
3. Hokota & Japanese Red Cedar, Moso Bamboo, Oaks Quercus spp. \\
4. Shimotsuma & Reed \\
5. Sakai & Madake P. bambusoides, Ginkgo Gynkgo biola \\
6. Tsukuba (Koike) & Cherry Prunus sp., Keyaki Zelkova serrata, other deciduous trees \\
6. Tsukuba (Doho) & Reed, Willow Salix giligiana \\
7. Noda & Moso Bamboo, Japanese Red Cedar \\
8. Iwatsuki & Reed \\
9. Ami & Willow \\
10. Toride & Reed, Willow \\
11. Azuma & Reed? \\
12. Kamisu* & Reed? \\
13. Hasaki* & Keyaki \\
14. Kitanarashino* & \\
\hline
\end{tabular}

The roosts with asterisks $\left(^{*}\right)$ are those located based on information through personal communications.

Table 3. Number of years and period of successive summer roost occupation in eastern Kanto area. The numbers on the left column correspond to those in Table 1 .

\begin{tabular}{ccl}
\hline \hline Roost & \multicolumn{1}{c}{ Years } & \multicolumn{1}{c}{ Period } \\
\hline 1. & $>40^{* *}(1)$ & end of June-mid-October (1) \\
2. & $>10^{* *(1)}$ & end of June-mid-October (1) \\
unknown \\
4. & $>6^{* *}(1)$ & end of June-mid-October (1) \\
5. & unknown & unknown \\
6. & $>10^{*}(1)$ & mid-June-mid-October (2) \\
$6^{\prime}$. & $>7^{* * *}(2)$ & mid-June-mid-October (2) \\
7. & $>3^{*}(2)$ & mid-June-mid-October $(2)$ \\
8. & $>12^{* *}(1)$ & end of rainy season-autumn $(1)$ \\
9. & unknown & mid-June-mid-October $(2)$ \\
10. & unknown & early July-autumn (1) \\
11. & unknown & unknown \\
12. & unknown & unknown \\
13. & $>3 * *(1)$ & unknown \\
14. & late June-autumn (1)
\end{tabular}

(1) Data obtained by inquiries.

(2) Data obtained by our observation.

* until 1985, ** until 1986, *** until 1992.

of the original roost site.

Table 2 shows the vegetation types of summer roost sites. Grey Starling did not seem to show a preference for a specific vegetation type.

Age and season of occupations of summer roosts are shown in Table 3 . Of the 8 summer roosts for which the years of occupation was determined based on inquiries 


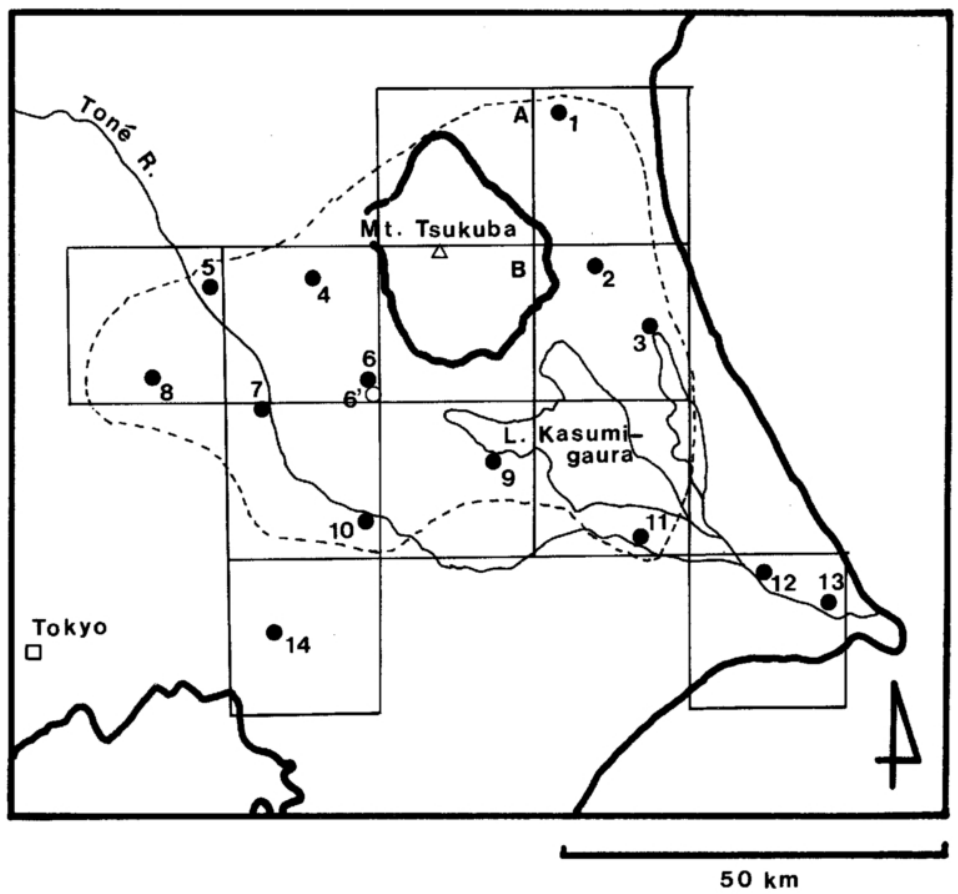

Fig. 1. Map of the study area. The solid circles indicate the location of the summer roosts. The numbers correspond to those in Tables 1,2 and 3 . The area within the broken line is where we searched for summer roosts. The $20 \times 20 \mathrm{~km}$ quadrats drawn on the map were used for the calculation $I_{\delta}$.

and personal observation, 6 were repeatedly occupied for more than 6 years. It may be worth noting that the roost in Mito (No. 1) is very old and said to have been already in existence shortly after World War II. Season of occupation was determined for 9 summer roosts. Eight of them were first occupied in mid- or late June and abandoned in mid-October. One was said to be occupied from around the end of the rainy season (early July) to autumn when leaves started to fall.

The location of summer roosts is shown in Figure 1. The $I_{\delta}$ index of nearest neighbor analysis was 0.4945 (thus, $I_{\delta}<1$ ), indicating that they were of uniform distribution ( $F$-test: $F<2.275 P<0.05$ ). Roost No. 6, rather than No. 6 ' was used for the calculation, because it was the original roost site which the starlings occupied undisturbed by human activities. The quadrats A and B were excluded from the calculation, as Grey Starlings were not found in these mostly mountainous and densely wooded areas. The mean distance between the neighboring roosts was calculated to be $17 \mathrm{~km}$.

\section{DISCUSSION}

Previous reports on the existence of summer roosts of the Grey Starling and the European starling Sturnus vulgaris either dealt with fewer summer roosts or were based on questionnaires (Davis 1970, Kuroda 1960, 1962, Maccarone 1987, NARusue et al. 1987, TAKENAKA et al. 1987). Thus, the distribution pattern of summer roosts 
was not clear. Our study showed that summer roosts in the eastern Kanto area were uniformly distributed and that many of them were used in successive years.

Uniform distribution of summer roosts might mean that the range that Grey Starlings travel and forage within a day are similar among the roosts. A uniform distribution of summer roosts might make it possible for them to come across a roosting site or to find flocks heading for a roost with little effort. However, more detailed study is necessary to understand the factors involved in this uniform distribution of summer roosts.

In summer, Grey Starlings did not seem to favor a certain vegetation type for roosting. This is in contrast to the fact that they roost almost exclusively in bamboo woods in the Kanto and Shin-etsu areas in winter (HANEda et al. 1967, Mizuguchi unpubl., TAKENAKA et al. 1987). This also suggests that during summer the position of roost site may be more important than the vegetation type of roost woods.

All of the summer roosts found in our study area were abandoned in mid-october, regardless of vegetation type (Tables 2 and 3). While deciduous trees shed leaves, becoming unsuitable for roosting around this time, the bamboo and cedar woods, which are green throughout the year, were also abandoned (Table 2). NARUsue et al. (1987) also reported that a summer roost in Saitama was abandoned in October. DAvis (1970) found that European Starlings abandoned summer roosts in October; he related the change in flock size with gonadal change in the starlings. CACCAmise $e$ al. (1983) also observed the abandonment of many summer roosts of European Starlings in autumn.

KURODA (1960) related the sudden abandonment of summer roosts in mid-October with the harvest of rice, which results in a drastic change in foraging habitat. In recent years, however, most rice harvest begins and ends earlier to avoid damage

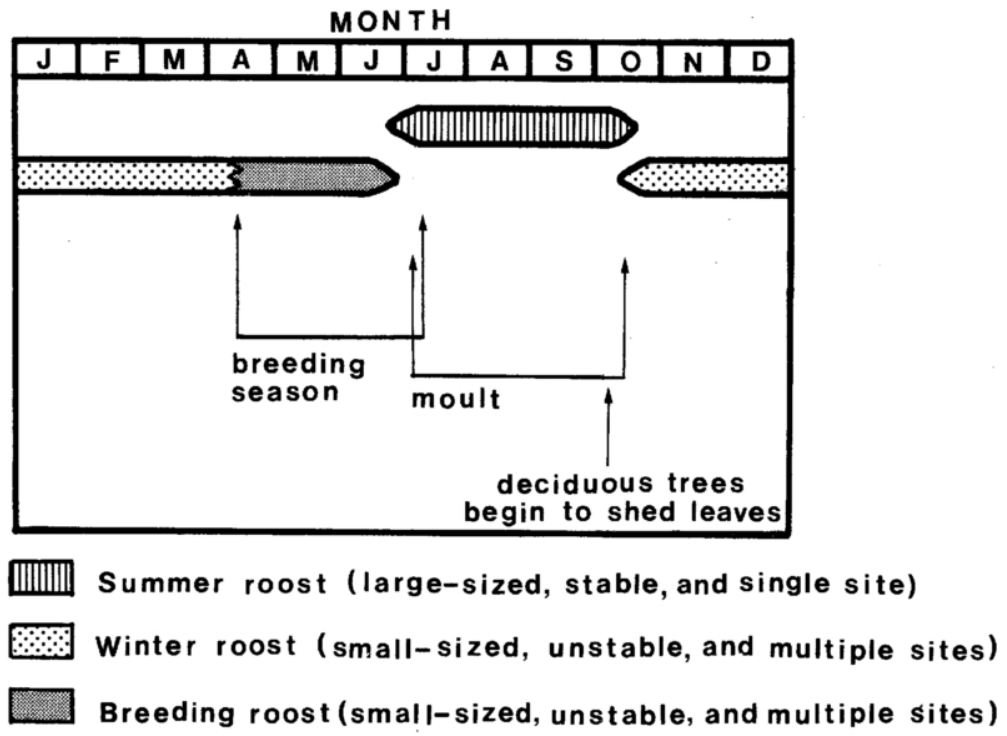

Fig. 2. A schematic diagram of the seasonal roosting behavior of the Grey Starling and other related events. Arrows indicate the beginning and the ends of each phenomenon. The duration of molt period is based on the data by KuRodA (1963) and our observation. 
from typhoons (Noguchi \& KawAda eds. 1991). This change in the timing of harvest did not make the timing of roost site abandonment earlier, indicating that a change in foraging substrate alone is not the determining factor for roost site abandonment.

In our study area, parent Grey Starlings with newly fledged young roosted in the small-numbered roosts found near their nesting sites between June and July (TAKENAKA pers. observ.). MACCARONE (1987) found that European starlings occupied numerous small-numbered roosts in early summer and suggested that this shift in roosting pattern was correlated with a change in diet.

As shown in Figure 2, several factors, including growth stage of fledglings, molting, ripening of fruits and leaf fall in deciduous trees, seem to occur simultaneously with the seasonal changes in roosting pattern of the Grey Starling. Furthermore, some of these factors seem to occur simultaneously. It may be difficult to separate them. It is also probable that these factors are different in different areas. Careful examination of these factors should be necessary in order to clarify the relationship between a seasonal roosting pattern and the habitat.

We are grateful to Drs, K. Nakamura and S. Matsuoka for their helpful and critical comments. We are grateful also to N. KanZAKI, K. MochizUKi and N. ToyosaKi who gave us valuable and reliable information about the summer roosts in Chiba. We are indebted to Barbara G. André for kindly reviewing our English manuscript.

\section{LITERATURE CITED}

Caccamise, D. F., Lyon, L. A. \& Fischl, J., 1983. Seasonal patterns in roosting flocks of Starlings and Common Grackles. Condor 85: 474-481.

DAvis, G. J., 1970. Seasonal change in flocking behavior of Starling as correlated with gonadal development. Wilson Bull. 82: 319-329.

HANEDA, K., Ushiy AMA, H., TeRANiShi, K. \& SANo, M. 1967. Winter roosting flock of Grey Starling (Sturnus cineraceus) in the Zenkoji Basin in Nagano Prefecture I. Jap. J. Ecol. 17: 234-237. (In Japanese with English summary.)

KURoDA, N., 1955. Field studies on the Grey Starling, Sturnus cineraceus Temminck. I. From winter to breeding season. Misc. Rep. Yamashina Inst. Ornith. \& Zool. 1: 277-289. (In Japanese with English Summary.)

KURODA, N., 1960. Field studies on the Grey Starling, Sturnus cineraceus Temminck III. Roosting behavior from summer to autumn (1. Roosts in the eastern part of Tokyo). Misc. Rep. Yamashina Inst. Ornith. 2: 18-29. (In Japanese with English Summary.)

Kuroda N., 1963. Molting in young Gray Starlings. Misc. Rep. Yamashina Inst. Ornith. 3(4): 3447. (In Japanese with english Summary.)

KURODA, N., 1973. Fluctuation of winter roosting flock of Sturnus cineraceus at Koshigaya and the roost change to Omatsu. Misc. Rep. Yamashina Inst. Ornith. 7(1): 34-55. (In Japanese.)

Maccarone, A. D., 1987. Evidence for resource-based communal roosting by European Starlings. Bird Behav. 7: 49-57.

MorishitA, M., 1959. Measuring of the dispersion of individuals and analysis of the distributional patterns. Mem. Fac. Sci. Kyushu Univ. Ser. E. 2: 215-235.

Narusue, M., Okuzaki, M. \& Hirata, H., 1987. Grey Starlings in Tsurugashima/Sakado area (the utilization of a roost site and food in the urbanizing area). Tsurugashima Kenkyu 4: 70-78. (In Japanese.)

NiBE, T., 1979. Roosting of Grey Starlings pp. 268-284. In The Ecology of Wild Birds. 3. Taishukan Shoten, Tokyo. (In Japanese.)

Noguchi, Y. \& Kawada, S., 1991. The Grand Dictionary of Agriculture, 2nd ed., Yokendo, Tokyo. (In Japanese.) 
Takenaka, M., Nakamura, K., Kuroda, N. \& Sugimori, F., 1987. General status of Grey Starling in Japan - reports from 23 prefectures 2. Roost and inhabitation. Bull. Appl. Ornith. 7: 114. (In Japanese with English summary.)

(Accepted 14 April 1994) 
考えられた.

キッネは調查地で頻繁に観察されたが, 元来, 密な林床植生を有する林内環境を避け, より開けた 農耕地もしくは林内歩道を行動して採餉する. 当調查地内でも 1 つがいのキッネが毎年繁殖するが, 夏期には主として昆虫を食している.

ヘビ類については, アオダイショウとシマへビの 2 種が樹洞営巣性鳥類の巣に対する捕食者として 確認されているが, 地上巣に対する捕食については不明である.

これらのことから, 調査地での樹上巣を被う植生はそれほどカラスに対して効果をもたないが, 地 上のササを主体とする林床植生は, カラスの侵入を防ぐばかりでなく, キッネのような地上性捕食者 をむ防いでいたと考えられる.

\title{
関東地方東部におけるムクドリ Sturnus cineraceus の 夏侍の分布パターンと特徴
}

\author{
竹中万紀子・竹 中 践
}

北海道東海大学 $\mathbf{T} 005$ 札幌市南区南沢 5 条 1 丁目 1-1

関東ではムクドリ Sturnus cineraceus は夏侍に多くの個体が集合することが知られているが（黒田 19551973 など, 成末ら 1987, 竹中ら 1987), 広域にわたる夏侍の分布状況は明らかではない, 我々 は余り都市化していない関東東部でムクドリの夏侍を調查し, その空間分布を分析した，調查地は, 茨城, 千葉, 埼玉に及ぶ面積約 $3,000 \mathrm{~km}^{2}$ の地域で, 平坦な耕作地帯の中に農家の屋敷林が点在する （図 1). 調查は 1984-1986 年の 6 月-10月に行った. 日没前に, 侍に向かう群を車で追い, 時をつき とめた. 通常 500 個体以下が利用する繁殖地の近くの侍は, 突発的で数日しか使われないので, 夏塒 には含めなかった．これらの㭙の集合羽数と墛林の植生を調へ，利用時期，年数等の観察及び聞き取 り調查を行った．いくつかの夏埘では 2 度以上センサスを行った．発見した夏埘について， $I_{\delta}$ Index を計算した（森下 1959). $I_{\delta}<1$ であれば,一様分布である.これには私信により場所が判明した 3 埘 あ含めた (表 1).

夏侍への集合羽数は 1 万弱から 3 万羽であった. 1985 年に，つくばの 6 番の侍が付近の住民に強 制的に放棄させられた後, 約 1 力月間は色々な方法へ飛去したが, 最終的に元の腒から約 $2 \mathrm{~km}$ 離れ た所に埘が形成された（図 1, 表 1,2,3の「6'」). 埘林として特定の植生が選好されることはなかった (表 2). 利用年数が判明した 8 つの腒のうち 6 つは 6 年以上連続して利用されていた. 利用時期が判 明した 9 時のうち 8 つは 6 月中一下旬から 10 月中旬まで利用され, 1 つは梅雨明け頃から落葉開始の 頃迄利用された. $I_{\delta}$ Index は 0.4945 ( $F$ - 検定: $\left.F<2.275, p<0.05\right)$ で, 一様分布であった. 時間の平 均距離は約 $17 \mathrm{~km}$ だった.

ムクドリ等の夏塒の研究は少数の塒が対象だったり, アンケート調查に基づいたものが多い (DAVIS 1970, 黒田 1960,1962, MACCARONE 1987, 成末ら 1987, 竹中ら 1987). 本研究で関東東部 のムクドリの夏媵は均一分布しており., 何年も継続的に利用されることが明らかになった. CACCAMISE らも (1983) ホシムクドリ等の埘の一部は何年も継続して利用されると報告している.ムクドリ は特定は特定の植生を侍林として選好しなかった. これは関東・信越地方の冬侍の竹林への選好性と は対照的であり（羽田ら 1967, 水口 未発表, 竹中ら 1987), これあ夏侍は植生より侍の均一分布が 重要である可能性を示唆している. 調查地内の夏侍林は, 全て 10 月中旬に放棄された（表 2). 成末 
ら (1987) も埼玉の夏埘が 10 月に放棄されると報告している. ホシムクドリの埘の放棄時期も 10 月 頃という報告があり, DAvis(1970) はこの群サイズの変化を生殖腺の変化と関連づけている. 黒田 (1960) は採食地の急激な変化を伴う稲刈りと 10 月中旬の埘放棄を関連づけた. 近年, 台風の害を防 ぐため当時より早く稲を刈る傾向があるが, 稲刈り時期の变化によって時の放棄時期は変化していな い. これは採食場所だけが時放棄の決定要因ではない可能性を示す. MACCARONE (1987) は多くの集 合羽数の少ない時から少数の集合羽数の多い時への転換には食性の变化が関わっていることを示唆し た. 我々の調查地では親鳥と巣立ち直後の若鳥は, 営巣地付近に集合羽数の少ない時を一時的に形成 する. 若鳥はその様な埘に集合する間に, 充分な飛翔力の獲得等の成熟を待つと思われる. 夏塒の分 布パターンにあムクドリの生活史自体が深く関わっていることが考えられ, 多くの換羽中の未経験の 若鳥を伴ったムクドリの群にとってこのような夏埘の分布パターンは好都合かむしれない. 埘形成パ ターンと環境との関係の解明には雊や巣立ち直後の若鳥の成長過程も考慮すべきである. また, 図 2 に示されるように, 雊の成長, 換羽, 落葉, 果実の熟す時期等, 様々な要因がムクドリの就侍パター ンの変化時期にあらわれる. 